\title{
Pengaruh Role Overload, Role Conflict dan Role Ambiguity terhadap Kinerja Karyawan dengan Dukungan Sosial sebagai Moderating Variabel pada Karyawan PT Y di Surabaya
}

\author{
Dianing Kumalaretna \\ email:dhiekerja@gmail.com \\ Praptini Yulianti \\ Universitas Airlangga Surabaya
}

\begin{abstract}
This study aims to determine the level of job stress among production employees in a manufacturing company, to measure the level of employee performance, and test the effect of work stress of Role Overload, Role Conflict and Role ambiguty on employee performance. Then this study examined the role of moderation from social support (from supervisors and coworkers) about the relationship mentioned above. This research is a quantitative study using a questionnaire. All data were collected through a survey and filled by 50 production workers in a manufacturing company in Surabaya. The sampling method suitable for this study. PLS method is used for statistical data analysis. The results showed a significant negative relationship between role overload and performance, a non-significant negative relationship between role conflict and performance, a negative relationship between role ambiguity and performance. Support from coworkers and superiors has a significant moderating effect on role overload and role ambiguity.
\end{abstract}

Key word: Role Overload, Role Conflict, Role Ambiguity, Job Performance, Social Support. 


\section{PENDAHULUAN}

Keadaan dunia bisnis yang kompetitif, sengit, dan dinamis saat ini mengharuskan perusahaan untuk melakukan berbagai upaya agar tetap bertahan dalam jangka panjang. (Gupta, Smith dan Shalley, 2006, Findikh et al.,2015). Kompleksitas persaingan yang dihadapi oleh PT. Y berdampak pada upaya pengelolaan sumber daya manusia dalam rangka tetap menjamin ketersediaan tenaga kerja yang handal, profesional dan memiliki daya saing tinggi. PT. Y harus dapat mengelola dan melaksanakan fungsi manajemen perusahaannya secara profesional. Salah satu upaya yang dari segi efisiensi tenaga kerja yang dilakukan yaitu dengan memperkerjakan tenaga kerja seminimal mungkin untuk dapat memberikan kontribusi yang maksimal sesuai sasaran perusahaan.

Sifat pekerjaan telah banyak berubah di banyak sektor industri selama beberapa dekade terakhir. Organisasi modern mempertimbangkan stres kerja karyawan mereka sebagai masalah penting di tempat kerja. (Hoboubi et al., 2016). Berbagai macam masalah dan semakin beragamnya permasalahan yang terjadi di perusahaan membuat karyawan mengalami stress dalam pekerjaan sehari-harinya.

Fogarty et al., (2000:31-67) menyatakan terdapat tiga jenis role stress yaitu konflik peran (role conflict),ketidakjelasan peran (role ambiguity) dan kelebihan peran (role overload).Smith et al., 2017 meneliti efek langsung dan tidak langsung dari stressor peran yaitu roleoverload, role conflict, role ambiguity mengurangi pencapaian kinerja karyawan.

Setiap pekerja memiliki tingkat stress yang berbeda-beda, begitu pula dengan pekerjaan yang dilakukan oleh karyawan manufacture ini. Penelitian terhadap karyawan bagian produksi disebabkan karena terjadi penurunan kinerja yang sangat signifikan dari tahun ke tahunnya. Penurunan kinerja karyawan produksi dapat dilihat dari tiga tahun terakhir ini yang mengindikasi adanya penuruan kualitas dimana ditunjukkan dengan banyaknya retur yang dikembalikan dari customer atau pelanggan yang mengeluhkan hasil kualitas produksi tersebut.

Menurut Groen et al., 2016 Kinerja bagian produksi adalah bagian yang sangat penting dari Strategis Operasional, hal ini sesuai dengan menurut pendapat Evans, 2004; Franco-Santos et al., 2007, 2012; Ho et al., 2014; Melnyk et al., 2004yaitu menyimpulkan fungsi penting dari sistem pengukuran kinerja kontemporer adalah penerjemahan strategi ke dalam istilah operasional. Di sini, "operasional" mengacu pada kegiatan yang dibentuk oleh operator dan profesional. Orang-orang yang terlibat langsung dalam menciptakan produk adalah operator di pabrik.

Manajemen harus memiliki perencanaan yang tepat untuk semua sumber dayanya. Salah satu sumber daya ini yang strategis untuk organisasi adalah sumber daya manusia yang merupakan komponen penting untuk perencanaan strategis. Saat ini sumber daya manusia adalah faktor yang paling penting dari produksi dan menjadi asset. Salah satu perkembangan paling signifikan di bidang organisasi belakangan ini adalah semakin pentingnya perencanaan sumber daya manusia karena sumber daya manusia adalah asset. (Bagheri J, 2016).

Untuk mencegah atau mengurangi stres kerja agar tidak terjadi penurunan kinerja sumber dukungan sosial dapat mengurangi beban, menggambarkan dukungan sosial sebagai sumber daya sosial utama (Halbesleben, 2006; Hobfoll, 2001, 2002) efek moderasi dari dukungan sosial pada mengurangi hubungan stres perankaryawan.(Chiu et al.,2015).

\section{KAJIAN TEORI DAN PENGEMBANGAN HIPOTESIS Role Overload}

Sutherland and Cooper (2010; 78) Role Overload adalah jumlah yang harus kita lakukan, baik ini melibatkan kerja yang 
berlebihan, kebutuhan untuk bekerja dengan jam kerja yang panjang, shift kerja, mengelola orang lain).

Menurut Gharib et al., 2016 mengklasifikasikan beban kerja menjadi dua yaitu Role overload dan Role Lower load.Role overload dapat bersifat kuantitatif dan kualitatif. Caponetti, 2012 masih dalam penelitian Gharib et al., 2012 mengklasifikasikan Role Overload menjadi : Beban berlebih (overload), Beban berlebih (overload jumlah) dan Beban waktu (overload waktu).

Teori Huey dan Wickens (1993:55) menyatakan bahwa beban kerja mempengaruhi kinerja, beban kerja dapat berpengaruh negatif, pada saat beban kerja meningkat maka kinerja turun. Pada penelitian yang dilakukan Oron-Gilad, Szalma, Stafford, \& Hancock, (2008) dalam penelitian Yussoff. R et al., (2014) menunjukkan bahwa ada hubungan negatif antara beban kerja dan kinerja. Berdasarkan uraian dan hasil penelitian terdahulu maka hipotesis pertama dalam penelitian ini adalah :

$\mathrm{H}_{1}$. Bahwa Role Overload berpengaruh signifikan negatif terhadap kinerja karyawan.

\section{Role Conflict}

Rizzo et al., (1970) dalam Rizwan et al., (2014) mendeskripsikan role conflict sebagai ketidaksesuaian dalam potensi yang saling berhubungan yang memaksakan kinerja pekerjaan yang jelas.

Menurut Luthans (2013) ada tiga jenis konflik peran, yaitu konflik antara individu dan peran; konflik Intrarole; Konflik Interrole. Penelitian tentang role conflict ini ada beberapa hasil salah satunya Penelitian menurut Fogartyet al., (2000) mengatakan bahwa penelitian konflik peran tidak berpengaruh pada kinerja. Sejumlah penelitian yang dilakukan di berbagai sektor menunjukkan ada hubungan yang signifikan secara statistik antarakinerja pekerjaan dan role conflict(Babin dan Boles, 1998; Mohr dan Puck, 2007). Dan menunjukkan hubungan negatif antara role conflict dan kinerja karyawan (Bhagat et al., 2010; Akgunduz. Y, 2015). Berdasarkan uraian dan hasil penelitian terdahulu maka hipotesis pertama dalam penelitian ini adalah :

$\mathrm{H}_{2}$. Bahwa Role Conflict berpengaruh signifikan negatif terhadap kinerja karyawan.

\section{Role Ambiguity}

Role ambiguity mengacu pada harapan yang tidak jelas dan tidak jelas yang ditetapkan untuk karyawan,sedemikian rupa sehingga karyawan tidak yakin dengan apa yang diharapkanmereka (Katz \& Kahn, 1978 dalam Eatough et al.,2011). Menurut Rizzo et al., 1970 dalam penelitian Ozbag et al., 2014 ada empat jenis untuk mengukur role ambiguity yaitu kesamaran tentang tanggung jawab, ketidakjelasan dari sasaran-sararan kerja, kesamaran apa yang diharapkan oleh orang lain, kurang adanya timbal balik dari atasan atau ketidakpastian tentang unjuk kerja pekerjaan.

Pada Penelitian yang dilakukan Bandura \& Locke, 2003 dalam Gharibet al., (2016) menyimpulkan bahwa ketika karyawan mengalami ambiguitas peran mereka akan mempengaruhi kinerja karyawan.Berdasarkan uraian dan hasil penelitian terdahulu maka hipotesis pertama dalam penelitian ini adalah :

$\mathrm{H}_{3}$. Bahwa Role Ambiguityberpengaruh signifikan negatif terhadap kinerja karyawan.

\section{Kinerja}

Kinerja adalah konsep multikomponen dan pada tingkat fundamental seseorang dapat membedakan aspek proses kinerja, yaitu, keterlibatan perilaku dari hasil yang diharapkan (Borman, \& Motowidlo, 1993; Campbell et al., 1993; Roe, 1999; Pradhan et al.,2017).

Penilaian kinerja menurut Flippo,1986 antara lain kuantitas kerja, kualitas kerja, kreativitas karyawan, sikap yang menunjukkan kemampuan seorang karyawan utnuk bekerja sama dengan 
orang lain dalam menyelesaikan tugastugasnya, ketepatan mengelola waktu.

\section{Dukungan Sosial}

Menurut House dan Wells (1978) dalam penelitian House, (1981) dukungan sosial merupakan suatu transaksi interpersonal yang melibatkan bantuan dalam bentuk dukungan emosi, dukungan penilaian, dukungan informasi, dan dukungan instrumen yang diterima individu sebagai anggota jaringan sosial.

Menurut House 1981 dalam Moeller, C., et al 2013 dukungan sosial dapat diklasifikasikanmenurut sumber dukungan yaitu sumber dukungan dari tempat kerja, misalnya supervisor dan teman kerja dan sumber dukungan dari keluarga, misalnya suami atau istri, keluarga, teman atau sahabat. Jika menurut jenis dukungan, termasuk instrumental, emosional, informasi, dan dukungan penilaian.

Penelitian yang dilakukan oleh Yussoff. $\mathrm{R}$ et al., 2014 menunjukkan bahwa beban kerja berhubungan negatif dengan kinerja kerja, di mana dukungan sosial secara signifikan memoderasi hubungan negatif antara beban kerja dan kinerja.Penelitian Himle et al., 1989 dalam penelitian Beehr T.A \& Sharon Glazer, 2015 bahwa dukungan emosional dari supervisor dan rekan kerja memiliki hubungan memoderasi antara konflik peran, dengan peningkatan dukungan pengawas, bisa membantu efek dari konflik peran dan ambguitas peran yang ada di karyawan.Berdasarkan uraian dan hasil penelitian terdahulu maka hipotesis pertama dalam penelitian ini adalah :

$\mathrm{H}_{4}$. Bahwa dukungan sosial memoderasi pengaruhRole Overload terhadap kinerja karyawan

$\mathrm{H}_{5}$. Bahwa dukungan sosial memoderasi pengaruhRole Conflict terhadap kinerja karyawan

$\mathrm{H}_{6}$. Bahwa dukungan sosial memoderasi pengaruhRole Ambiguityterhadap kinerja karyawan

Oleh karena itu kerangka konseptual dapat digambarkan dalam gambar 1 .

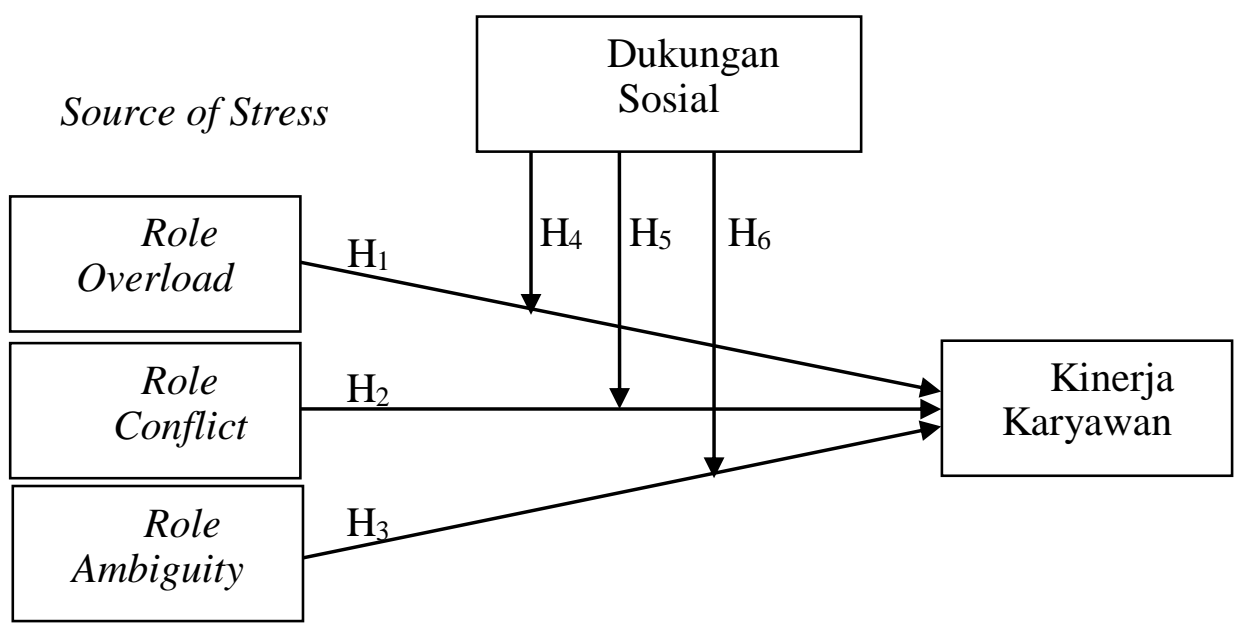

\section{METODE PENELITIAN}

Penelitian ini merupakan penelitian kuantitatif dengan menggunakan kuesioner. Pengukuran tiap indikator variabel-variabel dalam kuesioner penelitian ini dilakukan dalam bentuk skoring dengan menggunakan skala Likert, yang diimplementasikan melalui skala berjenjang 5 (five point scale). Data dikumpulkan melalui survei kepada 50karyawan produksi salah satu perusahaan manufacture di Surabaya, Jawa Timur, Indonesia. Teknik analisis data yang digunakan untuk pengujian antara lain: uji validitas, uji reliabilitas, dan kemudian dilanjutkan dengan Partial Least Square (PLS). 
HASIL DAN PEMBAHASAN

Penelitian telah melakukan survei dan uji validitas, uji reliabilitas dan PLS, berikut ini merupakan statistik deskriptif dalam penelitian ini :

Tabel I. Profil demografi responden

\begin{tabular}{l|ll|}
\hline \multicolumn{1}{l|}{$\begin{array}{l}\text { Informasi Demografi } \\
\text { Umur } \\
<25 \text { tahun }\end{array}$} & Frekuensi & Persen \\
25- 35 tahun & 9 & 18 \\
35 - 45 tahun & 24 & 48 \\
& 17 & 34 \\
Jenis Kelamin & & \\
Laki-laki & 50 & 100 \\
Perempuan & 0 & 0 \\
Masa Kerja & & \\
1 - 2tahun & & 38 \\
3-4 tahun & 19 & 26 \\
>4 tahun & 13 & 36 \\
\hline
\end{tabular}

Dalam tabel I, informasi demografi menunjukkan bahwa rata-rata dari 50 responden, $48 \%$ berumur $25-35$ tahun, $34 \%$ berumur 35-45tahun. Sedangkan $18 \%$ responden dalam kategori kurang dari 25tahun. Pembagian jenis kelamin dari responden, $100 \%$ responden adalah lakilaki. Masa kerja dari 50 responden menunjukkan bahwa jangka waktu terpendek dan terpanjang adalah $38 \%$ dan $26 \%$.

Tabel II. Pengujian Hipotesis Langsung

\begin{tabular}{|c|l|r|r|l|}
\hline \multicolumn{2}{|c|}{ Hipotesis } & $\begin{array}{r}\text { Koefisien } \\
\text { Pengaruh }\end{array}$ & $\begin{array}{c}\text { T- } \\
\text { Statistics }\end{array}$ & Signifikan \\
\hline $\mathrm{H}_{1}$ & $R O \rightarrow$ Kinerja & $-0,2058$ & 3,8858 & Signifikan \\
\hline $\mathrm{H}_{2}$ & $R C \rightarrow$ Kinerja & 0,0037 & 0,6568 & $\begin{array}{c}\text { Tidak } \\
\text { Signifikan }\end{array}$ \\
\hline $\mathrm{H}_{3}$ & $R A \rightarrow$ Kinerja & $-0,3768$ & 4,7919 & Signifikan \\
\hline $\mathrm{H}_{4}$ & $R O^{*}$ dukungan Sosial $\rightarrow$ Kinerja & $-0,2218$ & 2,4154 & Signifikan \\
\hline $\mathrm{H}_{5}$ & $R C^{*}$ dukungan Sosial $\rightarrow$ Kinerja & 0,0898 & 1,4913 & $\begin{array}{c}\text { Tidak } \\
\text { Signifikan }\end{array}$ \\
\hline $\mathrm{H}_{6}$ & RA*dukungan Sosial $\rightarrow$ Kinerja & $-0,1356$ & 2,0346 & Signifikan \\
\hline & & & & \\
\hline
\end{tabular}

Dapat dijelaskan uraian pengujian hipotesis dampak langsung sebagai berikut:

\section{Pengaruh role overload terhadap kinerja}

Hasil penelitian menunjukkan bahwa role overload (RO) berpengaruh secara signifikan terhadap kinerja dengan nilai $\mathrm{T}$ Statistics 3,8858> 1,96pada sampel karyawan produksi salah satu perusahaan manufacture di Surabaya. Dari hasil penelitian didapatkan bahwa keseluruhan indikator dari $\mathrm{RO}$ menunjukkan rata-rata nilai yang tinggi, sehingga persepsi yang muncul pada karyawan sebagai respon dari stres akibat kelebihan beban kerja yang dialami. Menurut penelitian yang dilakukan oleh Yusoff et al., (2014) bahwa jika beban kerja melebihi kemampuan karyawan maka hasilnya akan menurun kinerjanya. 
Pengaruh role conflict terhadap kinerja

Hasil penelitian menunjukkan bahwa role conflict (RC) mempunyai hubungan negatif tetapi berpengaruh secara tidak signifikan terhadap kinerja dengan nilai $\mathrm{T}$ Statistics $\quad 0,6568<1,96$ pada sampel karyawan produksi salah satu perusahaan manufacture di Surabaya. Dari hasil penelitian didapatkan bahwa keseluruhan indikator dari RC menunjukkan rata-rata nilai yang tinggi tetapi hasil menunjukkan tidak berpengaruh signifikan terhadap kinerja sehingga persepsi yang muncul pada karyawan sebagai respon dari stres akibat konflik peran namun tidak mempengaruhi kinerja. Menurut penelitian yang dilakukan oleh Fugarty et al., (2000) bahwa konflik peran tidak berpengaruh pada kinerja karena ketika muncul konflik peran maka individu terdorong untuk menggunakan strategi khusus dalam mengatasi konflik daripada menghindarinya.

\section{Pengaruh role ambiguity terhadap kinerja}

Hasil penelitian menunjukkan bahwa role ambiguity(RA) berpengaruh secara signifikan terhadap kinerja dengan nilai $\mathrm{T}$ Statistics 4,7919> 1,96pada sampel karyawan produksi salah satu perusahaan manufacture di Surabaya. Dari hasil penelitian didapatkan bahwa keseluruhan indikator dari RA menunjukkan rata-rata nilai yang tinggi, sehingga persepsi yang muncul pada karyawan sebagai respon dari stres akibat ketidakjelasan tanggung jawab yang dialami. Menurut penelitian yang dilakukan oleh Akgunduz Y, (2015) bahwa ambiguitas peran berpengaruh pada kinerja. Semakin ketidakjelasan yang dialami karyawan mengakibatkan menurunnya kinerja merka karena mereka tidak mengetahui apa yang seharusnya dilakukan.

\section{Pengaruh role overload terhadap kinerja dengan dukungan sosial sebagai variabel Moderasi}

Hasil penelitian menunjukkan bahwa sumber dukungan sosial memperkuathubungan antara role overload dengan kinerja karyawan. Hal ini didasarkan pada hasil perhitungan besaran koefisien pengaruh antara role conflict dan dukungan sosial terhadap kinerja dengan nilai T-Statistics 2,4154> 1,96pada sampel karyawan produksi salah satu perusahaan manufacture di Surabaya. Hasil penelitian ini mendukung penelitian yang dilakukan oleh Yussoff et al., (2014) yaitu di mana dukungan sosial dari rekan secara signifikan memoderasi hubungan antara beban kerja dan kinerja kerja. Dukungan sosial secara signifikan memoderasi hubungan negatif antara beban kerja dan kinerja.

\section{Pengaruh role conflict terhadap kinerja dengan dukungan sosial sebagai variabel Moderasi}

Hasil penelitian menunjukkan bahwa hipotesis kelima tidak dapat diterima, hal ini didasarkan pada hasil perhitungan besaran koefisien pengaruh antara role conflict dan dukungan sosial terhadap kinerja dengan nilai T-Statistics 1,4913< 1,96pada sampel karyawan produksi salah satu perusahaan manufacture di Surabaya. Oleh karena hubungan antara role conflict dengan kinerja tidak signifikan, maka dukungan sosial sebagai variabel moderasi tidak dapat dibuktikan secara statistik atau hipotesis ditolak.

Pengaruh role ambiguity terhadap kinerja dengan dukungan sosial sebagai variabel Moderasi

Hasil penelitian menunjukkan bahwa sumber dukungan sosial memperkuathubungan antara role ambiguity dengan kinerja karyawan. Hal ini didasarkan pada hasil perhitungan besaran koefisien pengaruh antara role ambiguity dan dukungan sosial terhadap kinerja dengan nilai T-Statistics 2,0346> 1,96pada sampel karyawan produksi salah satu perusahaan manufacture di Surabaya. Hasil penelitian ini mendukung penelitian yang dilakukan oleh ortqvist et al., (2016) yaitu di mana dukungan sosial dari rekan secara signifikan memoderasi hubungan antara ambiguitas dan kinerja kerja. Semakin tinggi dukungan sosial yang 
berasal dari supervisor maupun rekan kerja yang dirasakan karyawan maka bisa mengurangi pengaruh negatif dari role ambiguity dan meningkatkan kinerja.

\section{SIMPULAN DAN SARAN SIMPULAN}

1. Hipotesis pertama diterima. Role overload berpengaruh signifikan negatif terhadap kinerja karyawan.

2. Hipotesis kedua ditolak. Role conflict pengaruh tidak signifikan terhadap kinerja karyawan karyawan.

3. Hipotesis ketiga diterima. Role ambiguity berpengaruh signifikan terhadap kinerja karyawan.

4. Hipotesis keempat diterima. Bahwa dukungan sosial memoderasi pengaruhRole Overload terhadap kinerja karyawan.

5. Hipotesis kelima ditolak. Bahwa dukungan sosial memoderasi pengaruh Role Conflict terhadap kinerja karyawan tidak dapat dibuktikan secara statistik.

6. Hipotesis keenam diterima. Bahwa dukungan sosial memoderasi pengaruh Role Ambiguity terhadap kinerja karyawan.

\section{SARAN}

1. Penelitian selanjutnya diharapkan dapat menggunakan variabel-variabel lainnya yang dapat mempengaruhi kinerja.

2. Penelitian selanjutnya diharapkan dapat menguji efek moderasi dari variabel-variabel lainnya yang dapat memoderasi hubungan antar variabel.

\section{REFERENSI}

Akgunduz,Y.2015. The Influence of Selfesteem and Role Stress on Job performance in Hotel Businesses. International Journal of Contemporary Hospitality Management, Vol. 27, Issue6, pp.-.
Bagheri, J. 2016. Overlaps between Human Resources' Strategic Planning and Strategic Management Tools in Public Organizations. Procedia - Social and Behavioral Sciences, 203, pp. 430-438.

Beehr, T.A. dan Sharon, G., 2015. "A Cultural Perspective of Social Support in Relation to Occupational Stress". Exploring Theoretical Mechanisms and Perspectives, Vol. 1, pp. 97-142.

Bruggen, A. 2015. An Empirical Investigation of The Relationship between Workload and Performance. Management Decision, Vol. 53, Iss. 10 .

Caponetti, A.R. 2012. The Correlates of work Role Stress with Employee Burnout,Engagement.University of Tennessee, Knoxville.

Chiu, S.,Shih-Pin., dan Tun Chun Huang. 2015. Role Stressors and Employee Deviance: The Moderating Effect Social Support. Personal Review, Vol. 44Iss. 2, pp. 308-324.

Ortqvist Daniel.,Anna Oqvist., dan Malin Malmstrom. 2016. The Moderated Mediation Effect Of Social Support On Role Stress And Role Performance. International Journal of Psychology Research,Vol. 11, No.3-4.

Findikh, M. A.,Ugur Yozgat., dan Yasin Rofcanin. 2015. Examining Organizational Innovation and Knowledge Management Capacity. The Central Role of Strategi Human Resources Practices (SHRPs).Social and Behavioral Sciences, Vol. 181, pp. 377-387.

Groen, B. A. C., Marc, J.F.W., dan Celeste, P. M.W. 2016. Employee Participation, Performance Metrics 
and Job Performance A Survey Study Based on Self-determination Theory. International Journal ofManagement accounting Research, No. 16.

Gharib, M. N., Syeh, A. J., Moinuddin, A., dan Suhail, G. 2016. The Impact of Job Stress on Job Performance: A Case Study on Academic Staff at Dhofar University. International Journal of Economic Research, Vol. 13, No. 1, pp. 21-33.

Hoboubi, N., Alireza C., Fatemeh, K.G., Sareh, K., dan Ali A.H. 2017. The Impact of Job Stress and Job Satisfaction on Workforce Productivity in an Iranian Petrochemical Industry. The Journal of Safety and Health at Work, No. 8, pp. 67-71.

House, J. S.1981. Work stress and social support. Addison-Wesley Series on Occupational Stress.

Luthans, F., Milosevic, I., Bechky, B. A., Schein, E. H., Wright, S., Van Maanen, J., \& Greenwood, D. J. (2013). Reclaiming "Anthropology: the forgotten behavioral science in management history"commentaries. Journal of Organizational Ethnography,2(1), 92-116.

Moeller, C. dan Greg, A. C. 2015.Effects of Social Support on Professors Work Stress. International Journal of Educational Management. Vol. 27, Iss. 3, pp. 188-202.
Ozbag, G. K., Hulya, G, C., dan Gokce, C,C. 2014. Exploring The Effects of Perceived Organizational Impediments and Role Stress on Job Performance. International Strategic Management Conference. Vol. 150, pp. 1129-1136.

Pradhan, R. K., dan Lalatendu, K,J. 2017. Employee Performance at Workplace:Conceptual Model and Empirical Validation. Management Studies and Research SAGE Publication. Vol. 1, pp. 1-17.

Rizwan, M., Arooba Waseemdan Syeda Anam Bukhari,. 2014. Antecedents of Job Stress and its impact on Job Performance and Job Satisfaction.International Journal of Learning \& Development. Vol. 4, No.2.

Smith, K.,David J., dan George S., 2017. Stress Arousal And Burnout As Mediators Of Role Stress In Public Accounting. Advances in Accounting Behavioral Research,Vol. 20, pp.79116.

Sutherland, V., dan Ashley W., 2010. Organizational Stress Management. A Strategi Approach.,ISBN 978-1349-30157-7.

Yusoff, R., Anwar, K., Mazen F.R.,dan Alamzeb Aamir. 2014. Effect of Social Support on Faculty Workload and Performance. European Studies. Vol. 6, No. 2. 